\title{
Söğütlü Deresi (Trabzon) Su Kalitesi Parametrelerinin Coğrafi Bilgi Sistemleri Kullanılarak Değerlendirilmesi
}

\author{
Evaluation of Water Quality Parameters of Söğütlü River (Trabzon) Using Geographical \\ Information System
}

Arzu FIRAT ERSOY D, Duygu KARAGÜLLÜ $\mathbb{D}$

Karadeniz Teknik Üniversitesi, Jeoloji Mühendisliği Bölümü, TRABZON

Geliş (Received): 12 Eylül (September) 2017, Düzeltme (Revised): 04 Ekim (October) 2017, Kabul (Accepted): 14 Aralık (December) 2017

ÖZ

Tüm canlıların yaşam kaynağı olan ve içme, kullanma, enerji ve birçok amaç için kullanılan suya olan gereksinim her geçen gün artmaktadır. Su kaynaklarının plansız kullanımı günümüzdeki en önemli problemlerden biridir. Aşırı kullanım nedeniyle su kaynakları çevresel faktörlerden olumsuz etkilenmekte ve kirlenmektedir. Bu çerçevede su kaynaklarının yönetimi havza bazında sadece su miktarı yönünden değil, kalitesi açısından da önemlidir. Bu çalışmada, Trabzon ili Söğütlü Deresi ve yan kollarında 17 farklı noktadan alınan su örneklerinin hidrokimyasal özellikleri belirlenmiş, konumsal analiz teknikleri kullanılarak havza su kalitesi parametreleri açısından sınıflandırılmıştır. Söğütlü Deresi'nde çözünmüş oksijen (DO) değerleri 2.76-11.24 mg/l arasında; sertlik değerleri (FS) 5.1-21.8 FS arasında değişme göstermektedir. Yüzey suyunda pH değeri 6.63-7.5 arasında; elektriksel iletkenlik (EC) değeri 61-258 $\mu \mathrm{S} / \mathrm{cm}$ arasında ve toplam çözünmüş katı madde miktarı (TDS) 58-223 mg/l arasında değişmektedir. Söğütlü Deresi yüzey suyu "Kıta İçi Yüzeysel Su Kaynaklarının Sınıflarına göre Fe, Mn ve Al açısından II., III. ve IV. Sınıf sular sınıfinda yer almaktadır. Kirlilik parametreleri $\mathrm{NO}_{2}$ ve $\mathrm{NO}_{3}$ açısından da yine II., III. ve IV. Sınıf sular sınıfındadır. Söğütlü Deresi yüzey suyunda yapılan fiziksel, kimyasal ve kirlilik analizleri, yüzey suyunun son yıllarda özellikle çevre şartlarından olumsuz etkilenerek kirlendiğini ortaya koymuştur.

Anahtar Kelimeler: Su kalitesi, fiziksel ve kimyasal parametreler, IDW, Söğütlü Deresi, Trabzon

\section{ABSTRACT}

The need for drinking, use, energy and water for many purposes is increasing day by day as a source of life for all living things. Unplanned use of water resources is one of the most important problems today. Due to overuse, water resources are adversely affected and polluted by environmental factors. The management of water resources in this framework is important not only in terms of water quantity but also in terms of its quality. In this study, hydrochemical properties of water samples taken from 17 different points in Trabzon city Sögüutlü River and its branches were determined and the basin was classified in terms of different water quality parameters by using spatial analysis techniques. Dissolved oxygen (DO) values at Sögütlü Stream ranged from 2.76 to $11.24 \mathrm{mg} / \mathrm{l}$; Hardness values (FS) vary between $50.75-218.48 \mathrm{mg} / \mathrm{l}$. pH value in surface water is between 6.63 and 7.5; the electrical conductivity (EC) value is between $61-258 \mu \mathrm{S} / \mathrm{cm}$ and the total dissolved solids (TDS) is between 58 $223 \mathrm{mg} / \mathrm{l}$. Surface water of Sögütlü Stream classified as Fe, Mn and Al is in II., III. and IV category according to "Classifications of Inland Surface Water Resources". In terms of $\mathrm{NO}_{2}$ and $\mathrm{NO}_{3}$ pollution parameters, also water 
Fırat Ersoy, Karagüllü

class is in II., III. and IV. category. Physical, chemical and pollution analyses made on the surface water of Söğ̈̈tlü River show that surface water has been polluted in recent years due to unfavorable environmental conditions.

Keywords: Water quality, physical and chemical parameters, IDW, Sögütlü River, Trabzon

\section{GíRiş}

Yaşam için vazgeçilmez olan su kaynakları açısından ülkemiz bilinenin aksine su sıkıntısı çeken ülkeler arasına girmek üzeredir. Bunun nedeni, küresel 1sınma, aşırı ve bilinçsiz tüketim, alt yapı eksiklikleri ve su miktarındaki kayıplardır. Artan nüfusla birlikte kişi başına düşen su miktarı her geçen gün azalmaktadır ve bu sebeple yeraltı sularının yanı sıra yerüstü sularının kullanımı da artış göstermekte, yerüstü suları için kalite problemlerini değerlendirme ve geleceğe dönük çözümler üretme konusu önem kazanmaktadır.

Celep (2009), "Trabzon İli Yeraltı ve Yerüstü Sularının Hidrojeolojik, Hidrokimyasal İncelenmesi ve Su Kalitesinin İncelenmesi" isimli çalışmasında Trabzon ilinin yeraltı ve yerüstü sularını inceleyerek suların kimyasal açıdan karbonatlı ve sülfatlı sular sinıfında olduklarını belirlemiştir. Çalışma sonucunda, yüzey sularının "Su Kirliliği Kontrolü Yönetmeliği’ne" göre $\mathrm{Cu}$, $\mathrm{Pb}, \mathrm{Ni}, \mathrm{Al}$ ve Mn açısından II., III. ve IV. Sınıf sular sınıfında olduğu belirlenmiştir.

Gültekin vd. (2013), “Quality Assessment of Surface and Groundwater in Solaklı Basin (Trabzon, Turkey)" isimli çalışmasında Solaklı Havzasında 33 örnekleme noktasında yeraltı ve yüzey suyu çalışmaları yapmışlardır. Çalışma sonucunda hem iz element değerlerinin hem de kirlilik parametrelerinin nüfus merkezlerinde yoğunlaştığını belirleyerek gerekli tedbirlerin alınması gerektiğini vurgulamışlardır.

Ülkemizin birçok bölgesinde akarsular, kanalizasyon atıkları da dahil olmak üzere, organik maddeler tarafından aşırı derecede kirletilmektedir. Sanayi kentlerinde de yine akarsular, organik ve inorganik maddeler ile kirlenmektedir. $\mathrm{Bu}$ nedenle, yüzey sularının kalitesi çoğunlukla düşüktür. Yüzey sularının kalitesinin tanımlanması, "Su Kirliliği Kontrolü Yönetmeliği'nin" Kıta İçi Yüzeysel Sularının Sınıflandırılması ile yapılmaktadır. İçme sularının kalitesi ise "TSE 266 İnsani Tüketim Amaçlı Sular Standardı" ile tanımlanmaktadır. Kıta içi yüzeysel suların kalitelerine göre yapılan sınıflamalara göre; I. Sınıf: Yüksek kaliteli su; II. Sınıf: Az kirlenmiş su; III. Sınıf: Kirli su; IV. Sınıf: Çok kirlenmiş su olarak tanımlanmaktadır. Su kalitesini tanımlayan parametreler ve bunlara ait sınır değerleri I., II., III. ve IV. Sınıf için ayrı ayrı verilmiştir.

$\mathrm{Bu}$ çalışma ile ülkemizdeki su yönetiminin kurumsal yapısı dikkate alınmış $273 \mathrm{~km}^{2}$ alana sahip olan Söğütlü Havzası (Trabzon) yüzey suyu kalitesi problemleri ortaya konularak önerilerde bulunulmuştur (Şekil 1). Sögütlü Havzası yüzey suyu kalitesini belirlemek amacı ile, Sögütlü Deresi yüzey suyunda fiziksel parametreler, anyon-katyonlar, iz element ve kirlilik parametreleri analizleri yaptırılarak elde edilen sonuçlar irdelenmiştir. $\mathrm{Bu}$ değerlendirmeler hem "TSE 266 İnsani Tüketim Amaçlı Sular Sinıflaması" (TSE 266, 2014) ile hem de "Kita içi Yüzeysel Su Kaynaklarının Sınıfları" (Resmi Gazete, 2009) ile karşılaştırılmıştır. Ölçüm yapılan her nokta için temel hidrojeolojik bilgiler içeren bir veri bankası oluşturulmuştur. Oluşturulan bu veri bankasında sular kalite açısından sınıflandırılmış, içilebilme ve kullanılabilme özellikleri araştırılmıştır. Oluşturulan tematik haritalar, su sinıflama kriterleri ile değerlendirilip yorumlanmıştır. 


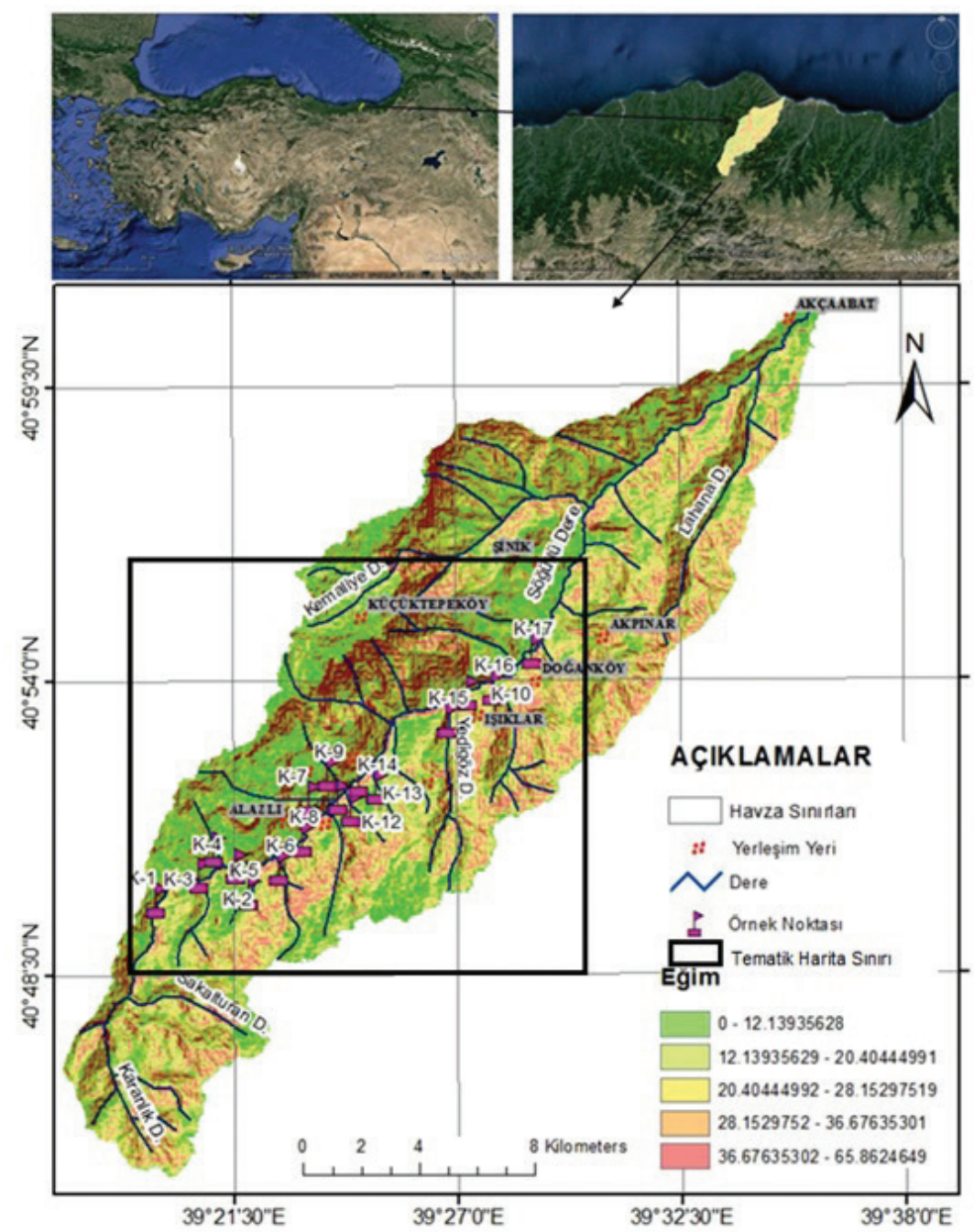

Şekil 1. Çalışma alanına ait yer bulduru haritası.

Figure 1. The location map of the study area.

\section{MATERYAL VE METOT}

Saha çalışmalarında, Sögütlü Deresinde yağışlı dönemde 17 örnek noktasında ana anyonkatyon, kirlilik ve iz element analizleri için çalışmalar yapılmıştır. Bu çalışmalar havzada kaynağa yakın mesafeden başlanarak yüzey suyu boyunca ana ve yan kollardan alınan örneklerle yapılmıştır (Şekil 1). Örnekleme işleminde SKKY Numune Alma ve Analiz
Metotları Tebliği (2009)'nde önerilen yöntemler uygulanmıştır. Örnek alınırken majör anyonkatyon, iz element ve kirlilik analizleri için 100 ml'lik polietilen şişeler kullanılmıştır. Numune almadan önce, numune alınacak su ile şişeler en az üç defa çalkalanarak kullanılmışlardır. Ölçüm yapılan her noktadan 2 ayrı örnek alınmış ve bu örneklerden birine metallerin çökmesini engellemek ve sağlıklı metal analizi sonuçları için $1 \mathrm{ml}$ nitrik asit eklenmiştir. 
Fırat Ersoy, Karagüllü

Örnekleme yapılan noktalarda sıcaklık (T), pH, elektriksel iletkenlik (EI), çözünmüş oksijen (DO), toplam çözünmüş madde miktarı (TDS), bulanıklık ve tuzluluk parametreleri YSI marka cihaz kullanılarak yerinde ölçülmüştür. Alınan örneklerin koordinatlarının belirlenmesinde Garmen Etrex Legend Cx marka el GPS' i kullanılmıştır.

Laboratuvarçalışmalarında yüzey sularından alınan $1 \mathrm{ml}$ nitrik asit eklenmiş olan $100 \mathrm{ml}$ 'lik su örneklerinin iz element ( $\mathrm{Fe}, \mathrm{Mn}, \mathrm{Al}, \mathrm{Cu}, \mathrm{Pb}$, $\left.\mathrm{Ni}, \mathrm{Co}, \mathrm{Cd}, \mathrm{As}, \mathrm{Cr}, \mathrm{F}^{-}\right)$analizleri yapılmıştır. Ana katyon $(\mathrm{Ca}, \mathrm{Mg}, \mathrm{Na})$ analizleri nitrik asitsiz olan $100 \mathrm{ml}$ su örnekleriyle ICP-OES yöntemi ile yapılmıştır. Ana anyonlar $\left(\mathrm{SO}_{4}^{2-}, \mathrm{Cl}^{-}\right)$ve kirlilik $\left(\mathrm{NO}_{2}^{-}, \mathrm{NO}_{3}^{-}\right)$analizleri ise nitrik asitsiz olan 100 $\mathrm{ml}$ su örneklerine Karadeniz Teknik Üniversitesi Jeoloji Mühendisliği Bölümü Uygulamalı Jeoloji Laboratuvarı'nda yapılmıştır.

\section{ÇALIŞMA ALANI VE ÇEVRESINIIN JEOLOJISI}

Türkiye'nin tektonik ve jeolojik birlikteliklerinden biri olan Doğu Pontidler, yapısal ve litolojik özellikler göz önünde bulundurularak Kuzey ve Güney Zon olarak tanımlanan iki ayrı bölgeye ayrılmıştır (Ketin, 1966). Kuzey Zon, Üst Kretase ve Orta Miyosen volkanik ve piroklastik kayaçlarla karakteristik iken; Güney Zon ise Üst Kretase öncesi tortul birimler ile karakteristiktir.

Doğu Pontid, Kuzey Zon içerisinde yer alan inceleme alanında, en altta yer alan Geç Jura- Erken Kretase yaşlı kireçtaşlarından oluşan Berdiga formasyonunun altında izlenen volkano-tortul karakterli birim Hamurkesen formasyonu olarak adlandırılmıştır. Berdiga formasyonu gri, bej renkli, orta-kalın tabakalı ve yer yer masif karbonatlardan meydana gelmiştir (Korkmaz, 1993). Çatak formasyonu, inceleme alanında Berdiga formasyonu üzerine uyumlu olarak gelen bazik karakterli volkano-tortul birimdir. Formasyon başlıca bazalt, andezit ve piroklastlar ile kumtaşı, silttaşı, marn, şeyl ve kırmızı-bordo renkli killi kireçtaşı düzeylerinin ardalanmasından oluşur. Çatak formasyonunu üsteleyen asidik karakterli kayaç ve piroklastlar Kızılkaya formasyonu olarak adlandırılmıştır (Güven, 1993). Kizılkaya formasyonu, çoğunlukla riyodasitik, dasit ve piroklastlardan oluşur. Çağlayan formasyonu ikinci evreli bazik karakterli volkanit, volkanoklastik ve çökel kaya ardalanmasından oluşan volkano-tortul birimdir. Çağlayan formasyonu'nun egemen kaya türünü oluşturan bazalt, andezit ve piroklastlarının arasında kumtaşı, marn ve kırmızı-bordo renkli killi kireçtaşı ara seviyeleri bulunur. İnceleme alanında türbiditik fasiyes çökellerinden oluşan birim, Bakırköy formasyonu, genel olarak killi, kumlu kireçtaş1, marn, şeyl ve az oranda kumtaş1 ardalanmasından oluşmuştur (Güven, 1998). Genellikle kırıntılı çökellerle başlayıp üst zonlara doğru volkanik karakterli istif ilk olarak Güven (1993) tarafindan Kabaköy formasyonu olarak tanımlanmıştır. İnceleme alanında yüzeylenen Kaçkar granitoyiti I (Kk1) ve Kaçkar granitoyidi II (Tk2) intrüzifleri; Eosen yaşlı Çağlayan formasyonu içinde izlenir. Genellikle gri, yeşilimsi gri, yer yer pembemsi renkte, çok kırıklı çatlaklı olan granitoyitler taneli veya porfirik dokuludur. Beşirli formasyonu, kaba taneli kırıntılı çökellerle başlayıp üst zonlara doğru tüflerle temsil edilmektedir. Çakıltaşı, kumtaşı ve tüflerden oluşan birim, Beşirli formasyonu, Kabaköy formasyonu üzerine uyumsuz olarak gelmektedir. Kuvaterner yaşı alüvyonlar, inceleme alanının havza sınırları içerisinde iç kesimlerinden doğan ve Karadeniz'e dökülen Söğütlü Deresi'nin denize yakın kesimlerindeki düzlük alanlarda çökelen kil, silt, kum, çakıl ve blok yığınlarından oluşan güncel oluşuklardır. İnceleme alanına ait jeoloji haritası Şekil 2'de verilmiştir. 


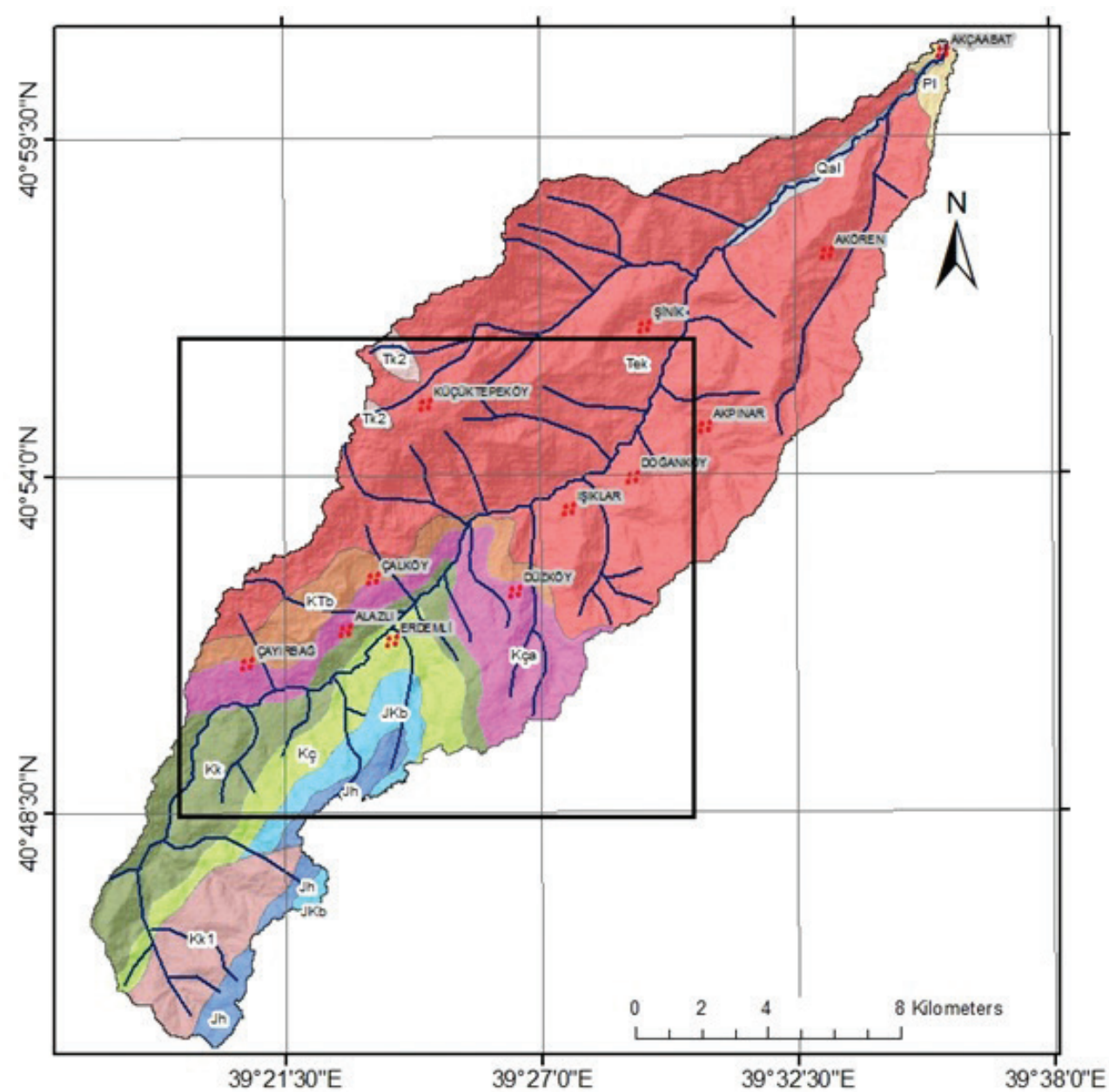

AÇIKLAMALAR

Havza Sını nan

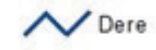

: Yerleșim Yeri

\section{Litoloji}
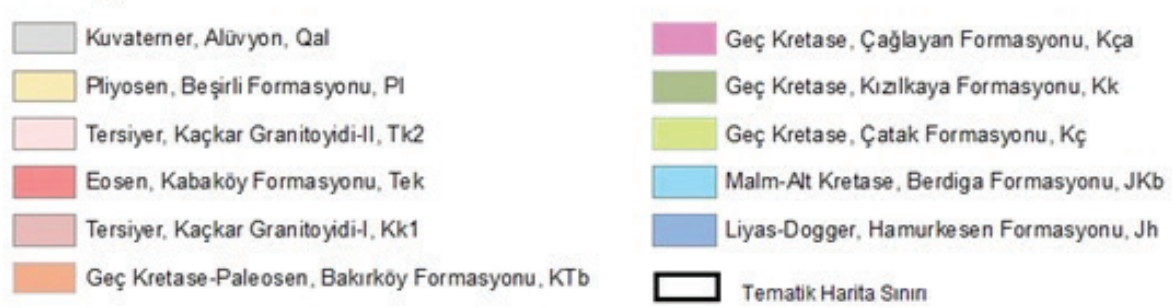

Şekil 2. Çalışma alanına ait jeoloji haritası (Güven, 1993, 1998).

Figure 2. The geological map of the study area (Güven, 1993, 1998). 
Fırat Ersoy, Karagüllü

\section{BULGULAR}

\section{Su Kimyası}

Söğütlü Deresi'nde 17 adet örnekleme noktasında yapılan yüzey suyu analiz sonuçları Çizelge 1, Çizelge 2 ve Çizelge 3'te verilmiştir. $\mathrm{Su}$ örneklerinin $\mathrm{pH}$ değerinin 6.63 ile 7.5 arasında, DO değerinin ise 2.76 ile $11.24 \mathrm{mg} / \mathrm{l}$ arasında değiştiği belirlenmiştir. Kıta içi yüzeysel su kaynaklarının sinıflarına göre su örnekleri DO açısından I. Sınıf ile IV. Sınıf arasında değişmektedir. Tüm örnekler elektriksel iletkenlik açsından değerlendirildiğinde I. Sınıf, TDS açısından ise tatlı su sınıfındadır.
Majör anyon ve katyon sonuçlarına göre tüm su örneklerinin TSE 266 Türk İçme Suyu Standardında tanımlanan sınır değerlerin altında bulunduğu ve kıta içi yüzeysel su kaynaklarının siniflarına göre I. Sınıf sular sinıfında olduğu görülmektedir (Çizelge 1).

Kimyasal analiz sonuçları iz elementler açısından değerlendirilmiştir. Analiz sonuçları incelendiğinde $\mathrm{Fe}$ değerlerinin $\mathrm{K} 1$ ve K5 örnekleri dışındaki tüm noktalarda TSE 266'da tanımlanan sınır değerlerin üzerinde bulunduğu görülmektedir. Kıta içi yüzeysel su kaynaklarının sinıflarına göre ise I. Sinıf ile IV. Sinıf sular arasında değişmektedir (Çizelge 2).

Çizelge 1. Söğütlü Deresi yüzey sularında bulunan fiziksel parametreler, majör anyon ve katyon değerleri (mg/L).

Table 1. Physical parameters, major anion and cation values $(\mathrm{mg} / \mathrm{L})$ in the Sögütlü River surface water.

\begin{tabular}{lllllllllllll}
\hline Örnek No & $\mathrm{T}\left({ }^{\circ} \mathrm{C}\right)$ & $\mathrm{pH}$ & $\mathrm{DO}$ & $\begin{array}{l}\mathrm{EI} \\
(\mu \mathrm{S} / \mathrm{cm})\end{array}$ & $\mathrm{TDS}$ & $\begin{array}{l}\text { Sertlik } \\
(\mathrm{FS})\end{array}$ & $\mathrm{Ca}$ & $\mathrm{Mg}$ & $\mathrm{Na}$ & $\mathrm{SO}_{4}^{2-}$ & $\mathrm{Cl}^{-}$ & $\mathrm{HCO}_{3}^{-}$ \\
\hline $\mathrm{K}-1$ & 8 & 7.5 & 11.24 & 61 & 58 & 5.1 & 15.4 & 2.99 & 2.39 & 6.22 & 2.263 & 48.8 \\
$\mathrm{~K}-2$ & 15.20 & 7.1 & 10.71 & 258 & 223 & 18.5 & 61.9 & 7.64 & 7.06 & 30.61 & 5.49 & 179.34 \\
$\mathrm{~K}-3$ & 15 & 7.36 & 9.7 & 250 & 217 & 21.8 & 71.1 & 9.96 & 5.76 & 4.96 & 1.62 & 248.88 \\
$\mathrm{~K}-4$ & 12.45 & 6.98 & 11.05 & 105 & 95 & 8.9 & 28.5 & 4.5 & 3.52 & 11.19 & 2.75 & 88.45 \\
$\mathrm{~K}-5$ & 16.52 & 7.17 & 9.41 & 136 & 114 & 11.8 & 37.9 & 5.88 & 1.82 & 7.48 & 1.52 & 126.27 \\
$\mathrm{~K}-6$ & 16.44 & 7.41 & 8.26 & 99 & 82 & 8.5 & 25.5 & 5.28 & 2.06 & 0.9 & 1 & 93.94 \\
$\mathrm{~K}-7$ & 10.43 & 6.89 & 8.53 & 185 & 78 & 13.4 & 46.8 & 4.33 & 3.36 & 0.87 & 1 & 159.82 \\
$\mathrm{~K}-8$ & 10.98 & 6.82 & $\underline{5.36}$ & 85 & 162 & 14.2 & 49.4 & 4.59 & 3.71 & 0.7 & 0 & 172.02 \\
$\mathrm{~K}-9$ & 13.22 & 7.25 & $\underline{4.57}$ & 152 & 130 & 13.8 & 46.7 & 5.29 & 4.57 & 0 & 0 & 167.75 \\
$\mathrm{~K}-10$ & 20.05 & 7.08 & $\underline{4.31}$ & 141 & 116 & 12.8 & 40.8 & 6.39 & 2.52 & 9 & 2.28 & 131.15 \\
$\mathrm{~K}-11$ & 10.67 & 6.63 & $\underline{3.68}$ & 119 & 107 & 11.3 & 38.5 & 4.38 & 2.98 & 5.84 & 1.66 & 125.66 \\
$\mathrm{~K}-12$ & 11.82 & 6.74 & $\underline{3.64}$ & 115 & 102 & 12.1 & 38.4 & 6.04 & 3.45 & 12.16 & 2.6 & 122 \\
$\mathrm{~K}-13$ & 12.03 & 7.02 & $\underline{3.74}$ & 125 & 109 & 13.6 & 43.3 & 6.89 & 3.61 & 12.38 & 2.62 & 139.08 \\
$\mathrm{~K}-14$ & 10.92 & 7 & $\underline{3.72}$ & 76 & 61 & 14.6 & 45.9 & 7.65 & 3.65 & 10.54 & 2.67 & 150.67 \\
$\mathrm{~K}-15$ & 9.5 & 6.72 & $\underline{3.52}$ & 109 & 94 & 12.3 & 39.2 & 6.21 & 1.88 & 6.82 & 1.77 & 128.71 \\
$\mathrm{~K}-16$ & 15.60 & 6.75 & $\underline{\underline{3.9}}$ & 100 & 100 & 11.4 & 37.7 & 4.89 & 2.97 & 4.7 & 1.52 & 126.88 \\
$\mathrm{~K}-17$ & 15.04 & 6.67 & $\underline{\underline{2.76}}$ & 143 & 119 & 13.4 & 65.5 & 9.67 & 4.9 & 12.78 & 2.93 & 216.55 \\
$\mathrm{TS} 266$ & & $6.5-9.5$ & $\underline{5}$ & 2500 & & & & & 200 & 250 & & \\
\hline
\end{tabular}


Çizelge 2. Söğütlü Deresi yüzey sularında bulunan iz elementler (değerler mg/L).

Table 2. Trace elements in the Sögütlü River surface water (values are $m g / L$ ).

\begin{tabular}{llllllllllll}
\hline Örnek No & $\mathrm{Fe}$ & $\mathrm{Al}$ & $\mathrm{Cu}$ & $\mathrm{Pb}$ & $\mathrm{Co}$ & $\mathrm{Mn}$ & $\mathrm{Ni}$ & $\mathrm{Cd}$ & $\mathrm{As}$ & $\mathrm{Cr}$ & $\mathrm{F}^{-}$ \\
\hline $\mathrm{K}-1$ & 0.165 & $\underline{0.343}$ & 0.006 & 0.003 & 0 & 0.024 & 0.001 & 0 & 0.001 & 0.003 & 0.125 \\
$\mathrm{~K}-2$ & $\underline{1.69}$ & $\underline{1.29}$ & 0.001 & $\underline{0.011}$ & 0.003 & $\underline{0.157}$ & 0.005 & 0 & 0.008 & 0.001 & 0.13 \\
$\mathrm{~K}-3$ & $\underline{2.73}$ & $\underline{1.49}$ & 0 & $\underline{0.012}$ & 0.003 & $\underline{0.178}$ & 0.010 & 0 & 0.008 & 0.001 & 0.07 \\
$\mathrm{~K}-4$ & $\underline{1.11}$ & $\underline{0.967}$ & 0.004 & $\underline{0.012}$ & 0.002 & $\underline{0.105}$ & 0.003 & 0 & 0.002 & 0.002 & 0.16 \\
$\mathrm{~K}-5$ & 0.074 & $\underline{0.210}$ & 0.005 & 0.008 & 0 & 0.026 & 0.001 & 0 & 0.003 & 0.003 & 0.09 \\
$\mathrm{~K}-6$ & $\underline{0.261}$ & $\underline{0.437}$ & 0.006 & 0.007 & 0.001 & 0.041 & 0.001 & 0 & 0.003 & 0.002 & 0 \\
$\mathrm{~K}-7$ & $\underline{0.429}$ & $\underline{0.450}$ & 0.004 & 0.009 & 0.001 & 0.045 & 0.001 & 0 & 0.004 & 0.001 & 0 \\
$\mathrm{~K}-8$ & $\underline{0.45}$ & $\underline{0.494}$ & 0.005 & 0.005 & 0 & 0.046 & 0.001 & 0 & 0.003 & 0.003 & 0 \\
$\mathrm{~K}-9$ & $\underline{1.93}$ & $\underline{1.86}$ & 0.002 & $\underline{0.012}$ & 0.003 & $\underline{0.170}$ & 0.006 & 0 & 0.004 & 0.002 & 0 \\
$\mathrm{~K}-10$ & $\underline{0.861}$ & $\underline{1.16}$ & 0.005 & 0.003 & 0.001 & $\underline{0.079}$ & 0.003 & 0 & 0.006 & 0.001 & 0.14 \\
$\mathrm{~K}-11$ & $\underline{3.52}$ & $\underline{2.37}$ & 0.003 & 0.005 & 0.003 & $\underline{0.203}$ & 0.005 & 0 & 0.004 & 0.001 & 0.09 \\
$\mathrm{~K}-12$ & $\underline{3.42}$ & $\underline{2.84}$ & 0 & $\underline{0.015}$ & 0.005 & $\underline{0.458}$ & 0.009 & 0 & 0.002 & 0.001 & 0.11 \\
$\mathrm{~K}-13$ & $\underline{4.55}$ & $\underline{3.66}$ & 0.002 & $\underline{0.016}$ & 0.006 & $\underline{0.569}$ & 0.010 & 0 & 0.006 & 0 & 0.13 \\
$\mathrm{~K}-14$ & $\underline{3.44}$ & $\underline{2.79}$ & 0.001 & 0.007 & 0.004 & $\underline{0.256}$ & 0.006 & 0 & 0.004 & 0 & 0.17 \\
$\mathrm{~K}-15$ & $\underline{1.51}$ & $\underline{1.99}$ & 0.003 & $\underline{0.013}$ & 0.001 & $\underline{0.137}$ & 0.003 & 0.001 & 0.001 & 0.001 & 0.12 \\
$\mathrm{~K}-16$ & $\underline{1.58}$ & $\underline{1.85}$ & 0.004 & 0.006 & 0.002 & $\underline{0.107}$ & 0.003 & 0 & 0.004 & 0.002 & 0.09 \\
$\mathrm{~K}-17$ & $\underline{7.12}$ & $\underline{6.02}$ & 0.009 & 0.016 & 0.008 & $\underline{0.604}$ & 0.017 & 0 & 0.006 & 0.001 & 0.12 \\
$\mathrm{TS} 266$ & 0.2 & 0.2 & 2 & 0.01 & & 0.05 & 0.02 & 0.005 & 0.01 & 0.05 & 1.5 \\
\hline
\end{tabular}

Mn için TSE 266' da tanımlanan sınır değer $0.05 \mathrm{mg} / 1$ dir. Çizelge 2 incelendiğinde $\mathrm{Mn}$ değerlerinin 0.024 ile 0.604 arasında değiştiği ve $\mathrm{K} \mathrm{2,} \mathrm{3,} \mathrm{4,} \mathrm{9,} \mathrm{10,} \mathrm{11,} \mathrm{12,} \mathrm{13,} \mathrm{14,} \mathrm{15,} \mathrm{16,} 17$ nolu su örneklerinde Mn değerinin sınır değeri aştığ1 belirlenmiştir. Kıta içi yüzeysel su kaynaklarının sınıflarına göre ise su örnekleri I. Sinıf sular ile III. Sınıf sular arasında değişmektedir.

Analiz sonuçları Al açısından değerlendirildiğinde, örneklerin tüm noktalarda sınır değer olan $0.2 \mathrm{mg} / \mathrm{L}$ 'nin üzerinde olduğu görülmüştür. Kıta içi yüzeysel su kaynaklarının sinıflarına göre I. Sinıf sular ile IV. Sinıf sular arasında değiştiği belirlenmiştir.
Çizelge 2 incelendiğinde, Söğütlü Deresi yüzey sularının $\mathrm{Pb}$ değerlerinin 0.003 ile 0.016 $\mathrm{mg} / \mathrm{L}$ arasında değiştiği görülmektedir. $\mathrm{Bu}$ değerler açısından kıta içi yüzeysel su kaynakları sınıflamasına göre I. ve II. Sınıf sular sinıfında yer almaktadır. Ayrica TSE 266'ya göre K 2, $3,4,9,12,13,15$ nolu örneklerin içme suyuna uygun olmadığı belirlenmiştir. Söğütlü Deresi yüzey sularının iz element analiz sonuçları incelendiğinde $\mathrm{Cu}, \mathrm{Ni}, \mathrm{Co}, \mathrm{Cd}, \mathrm{As}, \mathrm{Cr}$ ve $\mathrm{F}$ değerleri açısından kıta içi yüzeysel su kaynakları sinıflamasina göre I. Sinıf sular sinifinda yer aldığı belirlenmiştir (Çizelge 2). 
Fırat Ersoy, Karagüllü

Söğütlü Deresi'nde gerçekleştirilen 17 adet yüzey suyu örnek noktasına ait analiz sonuçları kirlilik parametreleri açısından incelenmiştir. Analiz sonuçlarına göre yüzey sularında $\mathrm{NO}_{2}$ değerleri 0-0.96 arasında değişmektedir. $\mathrm{Bu}$ değerler açısından için TSE 266'ya göre K1, 2, 3, 4, 11, 13, 14, 16 numaral1 örneklerin içmeye uygun olmadığı ve kıta içi yüzeysel su kaynaklarının sinıflarına göre I-IV. Sinıf sular sınıfında olduğu belirlenmiştir. Yüzey sularında $\mathrm{NO}_{3}$ değerleri 0-14.87 arasında değişmekte olup ve bu değerlere göre I ve II. ve III. Sınıf sular sınıfında bulunmaktadır (Çizelge 3).

Çizelge 3. Söğütlü Deresi yüzey sularında bulunan kirlilik parametreleri.

Table 3. Pollution parameters in the Sögütlü River surface water.

\begin{tabular}{llllll}
\hline Örnek No & $\mathrm{NO}_{2}^{-}$ & $\mathrm{NO}_{3}^{-}$ & Örnek $\mathrm{No}$ & $\mathrm{NO}_{2}^{-}$ & $\mathrm{NO}_{3}^{-}$ \\
\hline $\mathrm{K}-1$ & $\underline{0.87}$ & 5.21 & $\mathrm{~K}-9$ & 0 & 0 \\
$\mathrm{~K}-2$ & $\underline{0.96}$ & 14.87 & $\mathrm{~K}-10$ & 0 & 6.36 \\
$\mathrm{~K}-3$ & $\underline{0.74}$ & 2.83 & $\mathrm{~K}-11$ & $\underline{0.79}$ & 2.77 \\
$\mathrm{~K}-4$ & $\underline{0.72}$ & 8.15 & $\mathrm{~K}-12$ & 0 & 7.5 \\
$\mathrm{~K}-5$ & 0 & 3.55 & $\mathrm{~K}-13$ & $\underline{0.74}$ & 7.74 \\
$\mathrm{~K}-6$ & 0 & 0.85 & $\mathrm{~K}-14$ & $\underline{0.74}$ & 9 \\
$\mathrm{~K}-7$ & 0 & 0.82 & $\mathrm{~K}-15$ & 0 & 5.01 \\
$\mathrm{~K}-8$ & 0 & 0.77 & $\mathrm{~K}-16$ & $\underline{0.83}$ & 5.53 \\
& & & $\mathrm{~K}-17$ & 0 & 8.37 \\
TS266 & 0.5 & 50 & & 0.5 & 50 \\
\hline
\end{tabular}

\section{IDW Yöntemi ile Söğütlü Deresi’nde tematik} haritaların oluşturulması

Söğütlü Havzası için, ARCGIS yazılımı kullanılarak sayısal yükseklik modeli (SYM), eğim haritası ve 3 boyutlu arazi modeli (TIN) oluşturulmuştur. Birhavzanın ortalama yükssekliği, sıcaklık ve yağışı etkilemektedir. Sıcaklık, yağış, bitki örtüsü verileri de havza hidrojeolojisini doğrudan etkiler. Havza hidrojeolojisinin tanımlanmasında ARCGIS yazılımına ait ArcHydro modülü kullanılmıştır. ArcHydro modülü kullanılarak havza sınırları ve havzadaki yüzey sularının akış yönü belirlenmiştir.

$\mathrm{Bu}$ çalışma kapsamında toplanan su kimyası verilerinin ve ölçümü yapılan noktaların koordinatları ve niteliksel özellikleri Excel formatından ArcGIS 10.1 Coğrafi Bilgi Sistemleri yazılımı modülüne aktarımı ile gerçek uzay koordinatlarına sahip noktasal verilerin depolama işlemi gerçekleştirilmiştir. Analiz işlemi sırasında veri tabanında saklanan nokta özellikleri ve su kalitesi değerleri analiz edilmiştir. ArcGIS jeoistatistiksel analiz modülü kullanılarak analiz edilmiş ve jeoistatistiksel veri modelleri oluşturulmuştur. Verinin olmadığ 1 noktalar için yapılan tahminler, IDW (Ters Ağırlıklı Mesafe) yöntemi kullanılarak yapılmıştır. ArcGIS jeoistatistiksel analiz modülü uygulama akış şeması Şekil 3'te verilmiştir.

Söğütlü Deresi'nde yapılan 17 adet örnekleme noktasina ait veriler ARCGIS 10 modülü olan IDW (Inverse Distance Weighting) tekniği ile değerlendirilmiş ve tematik haritalar oluşturulmuştur. IDW tekniği enterpole edilecek yüzeyde yakındaki noktaların uzaktaki noktalarda daha fazla ağırlığa sahip olması esasına dayanmaktadır. $\mathrm{Bu}$ teknik enterpole edilecek noktadan uzaklaştıkça ağırlığı da azaltan ve örnekleme noktalarının ağırlıklı ortalamasına göre bir yüzey enterpolasyonu yapmaktadır. 


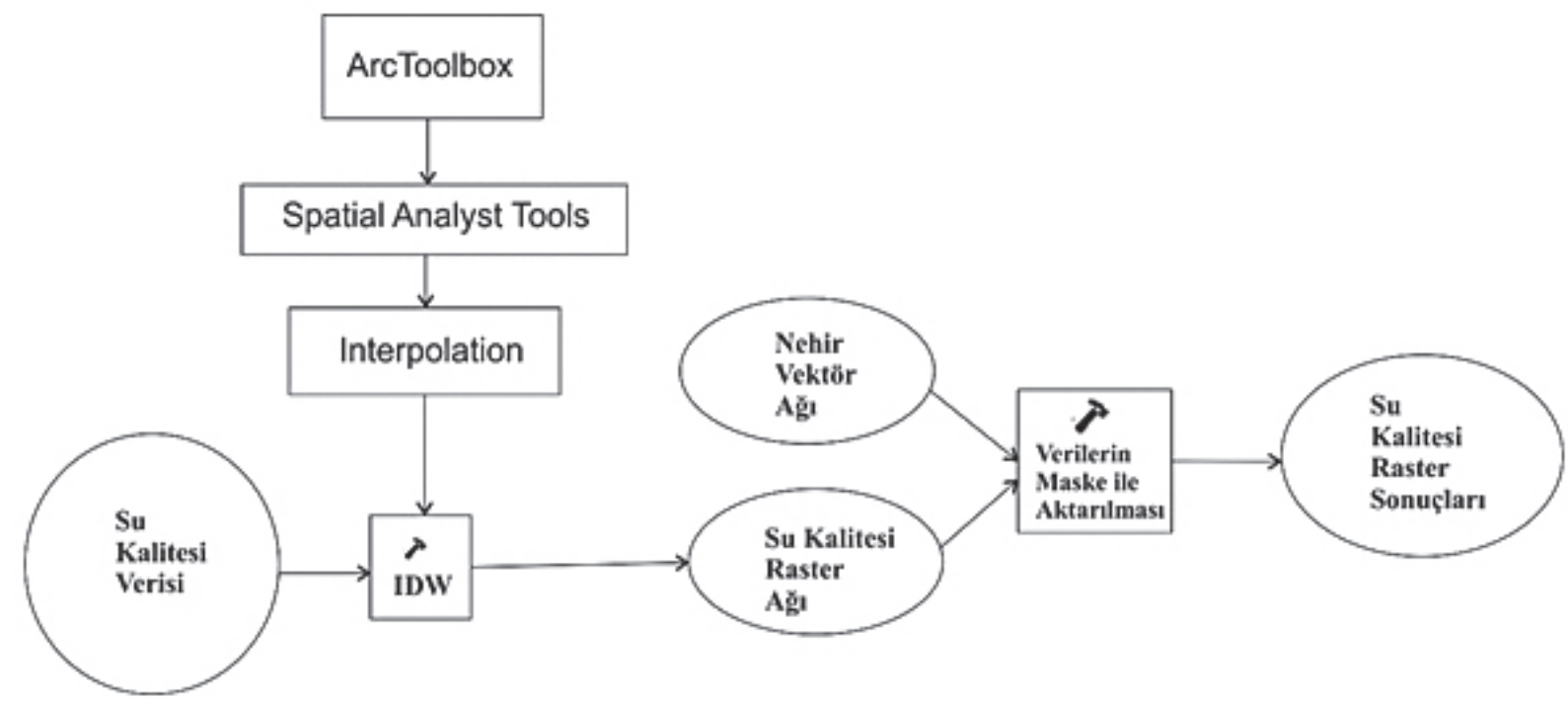

Şekil 3. ArcGIS jeoistatistiksel analiz modülü uygulama akışşeması.

Figure 3. Application flowchart of ArcGIS geostatistical analysis module.

$\mathrm{Bu}$ çalışmada, Sögütlü Deresi yüzey suyunda 17 örnekleme noktasında IDW tekniği kullanılarak, her bir hücre için nehir ağını maskeleme işlemi yapılmış ve nehir ağındaki hücreler su kalitesi verilerini yorumlayabilmek için su kalitesi ağına dönüştürülmüştür.

Söğütlü Havzası yüzey suyunda 17 noktadan elde edilen fiziksel parametreler, majör anyon ve katyon değerleri ve kirlilik parametreleri için IDW yöntemi ile tematik haritalar hazırlanmıştır.

DO değerleri için hazırlanan tematik haritada, değerlerin Söğütlü Deresi'nde akış yönünde yani güneyden kuzeye doğru arttığ1 görülmektedir. Sertlik değerleri için hazırlanan haritada, Sögütlü Deresi yüzey suyunun genellikle "çok yumuşak sular" ile "oldukça sert sular” sınıfında olduğu görülmektedir (Şekil 4).
$\mathrm{Fe}, \mathrm{Mn}, \mathrm{Al}$ ve $\mathrm{Pb}$ değerlerine göre hazırlanan tematik haritalarda, Söğütlü Deresi'nde akış boyunca güneyden kuzeye doğru değerlerde artış gözlenmektedir. Kıta içi yüzeysel su kaynaklarına göre değerlendirildiğinde, yukarıda ad1 geçen değerler açısından akarsuda kirlenme söz konusudur. Söğütlü yüzey suyunda güneyden kuzeye doğru su kalitesinde azalma gözlenmiştir (Şekil 5 ve 6).

Kirlilik parametreleri için hazırlanan haritalarda $\mathrm{NO}_{2}$ değerleri açısından neredeyse tüm ölçüm noktalarında IV. Sınıf sular sınıfında olduğu yani yüzey suyunda kirlilik oluşturduğu belirlenmiştir. $\mathrm{NO}_{3}$ değerleri incelendiğinde ise Söğütlü Deresi yüzey suyunun kuzey kesimlerinde değerlerin yükseldiği, II. ve III. Sınıf sular şeklinde bulunduğu görülmektedir (Şekil 7). 
Fırat Ersoy, Karagüllü
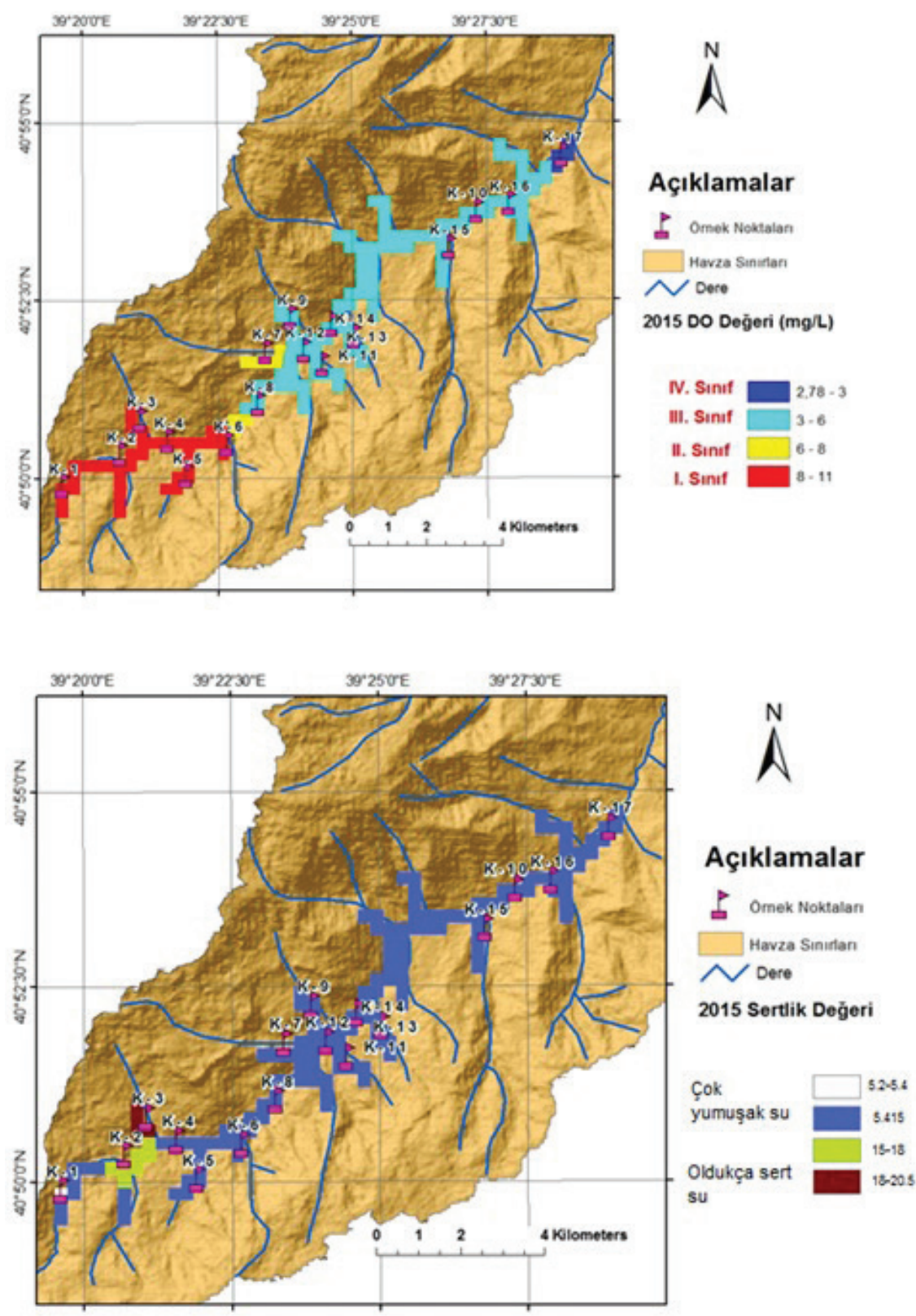

Şekil 4. Söğütlü Havzası'nda DO ve sertlik değerleri için hazırlanan tematik harita.

Figure 4. Thematic map prepared for DO and hardness values in the Sögüttlü Basin. 


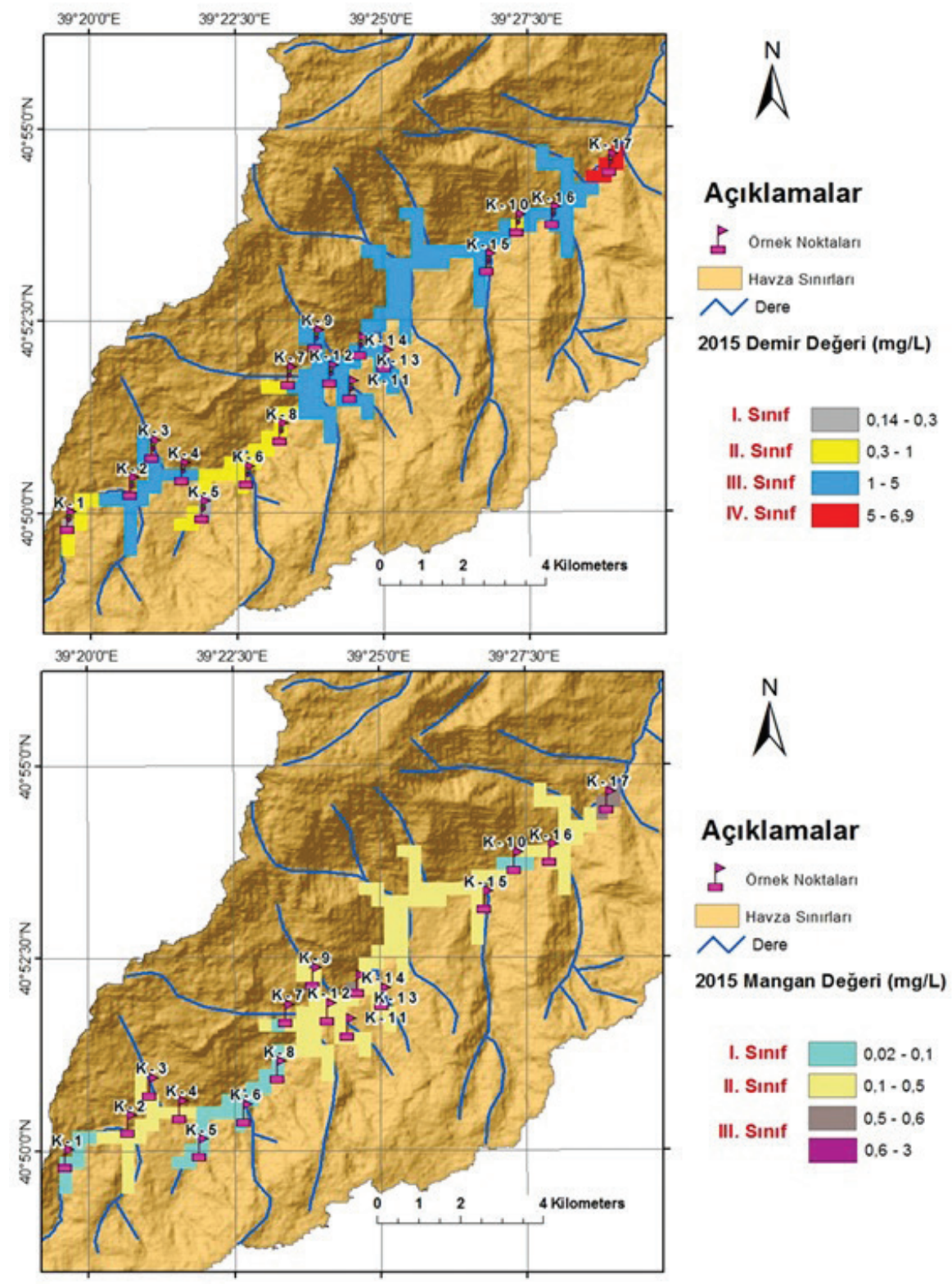

Şekil 5. Söğütlü Havzası'nda Fe, Mn değerleri için hazırlanan tematik harita.

Figure 5. Thematic map prepared for Fe, Mn values in the Sögütlü Basin. 
Fırat Ersoy, Karagüllü

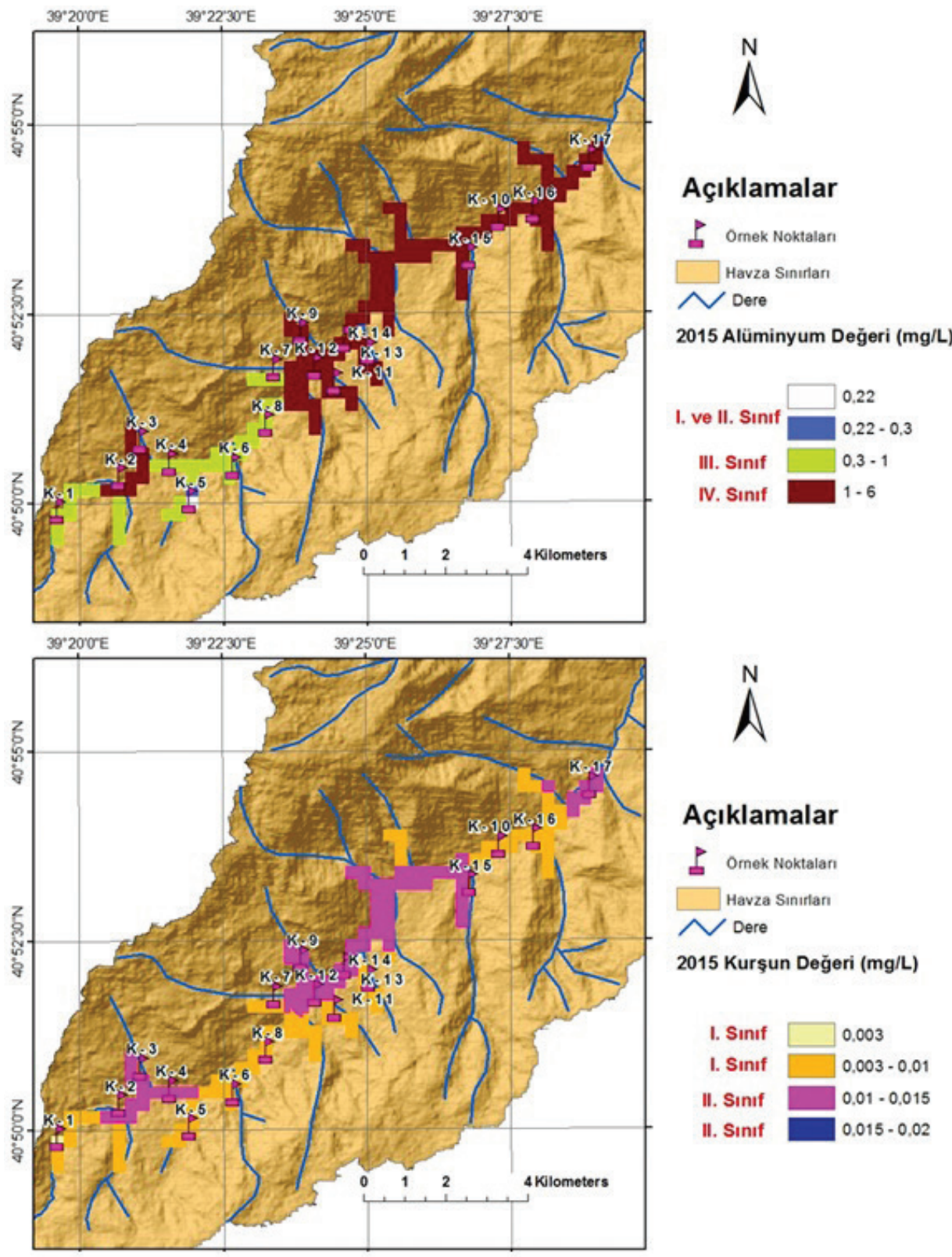

Şekil 6. Söğütlü Havzası'nda $\mathrm{Al}$ ve $\mathrm{Pb}$ değerleri için hazırlanan tematik harita.

Figure 6. Thematic map prepared for Al ve Pb values in the Sögütllü Basin. 


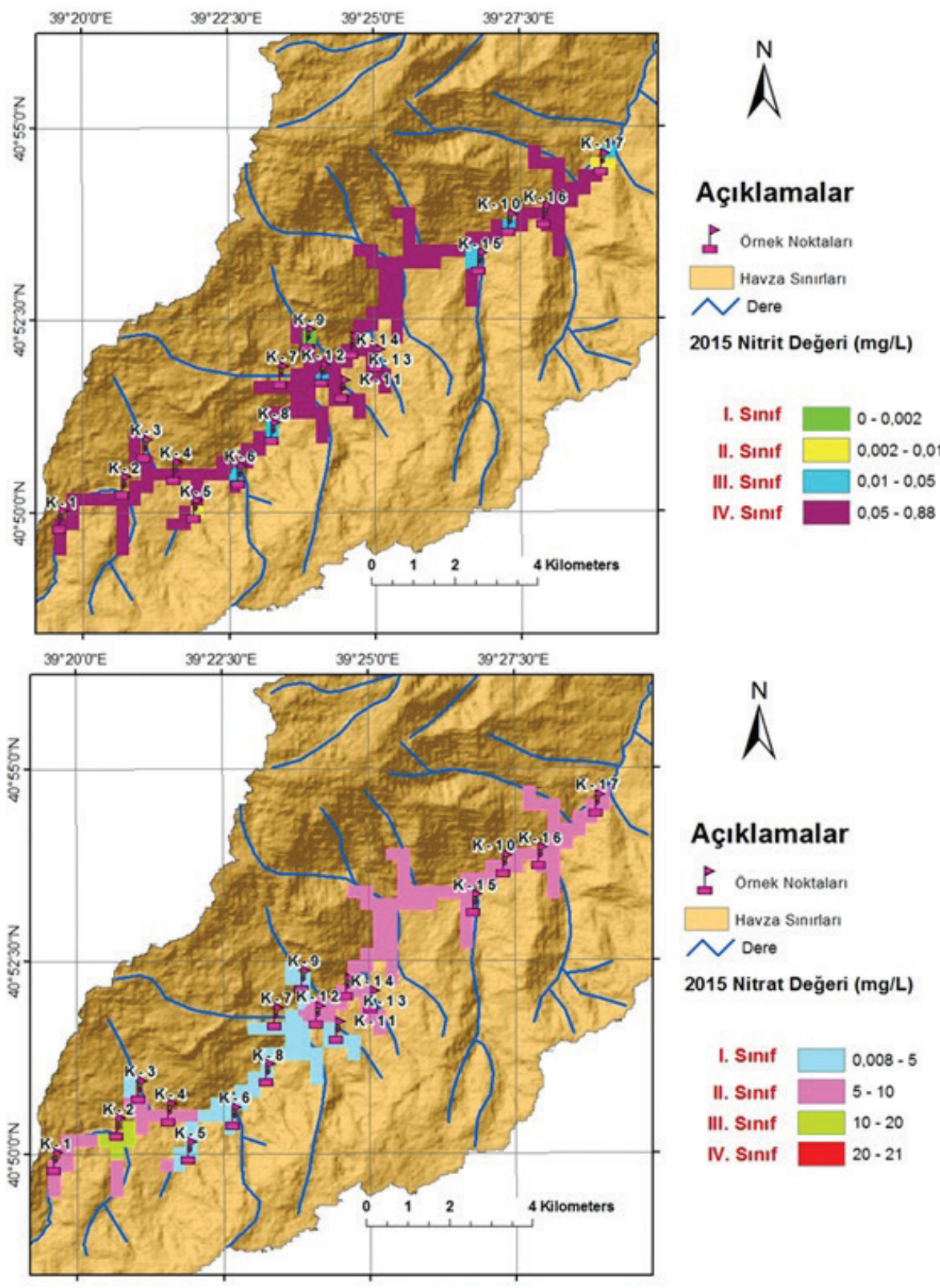

Şekil 7. Söğütlü Havzası'nda $\mathrm{NO}_{2}$ ve $\mathrm{NO}_{3}$ değerleri için hazırlanan tematik harita.

Figure 7. Thematic map prepared for $\mathrm{NO}_{2}$ ve $\mathrm{NO}_{3}$ values in the Sögütlü Basin. 
Fırat Ersoy, Karagüllü

\section{SONUÇLAR}

Suların fiziksel, kimyasal ve biyolojik olarak kirlenmesi nedeni ile suların kalitesinde değişiklikler meydana gelmektedir (Kara ve Çömlekçioğlu, 2004). Bu çalışmada Trabzon ili Söğütlü Deresi'nde akış istikametinde güneyden kuzeye doğru 17 örnekleme noktasında fiziksel, kimyasal ve kirlilik parametreleri analiz edilerek yüzey suyunda su kalitesi belirlenmeye çalışılmıştır. Analiz sonuçları hem TS266 İnsani Tüketim Amaçlı Sular Sınıflaması ile hem de Kıta İçi Yüzeysel Su Kaynaklarının Sınıflarına göre değerlendirilmiştir.

Fiziksel parametreler açısından irdelendiğinde $\mathrm{pH}$ değerlerine göre Söğütlü Deresi yüzey suyu tüm örnekleme noktalarında I. Sınıf sular sınıfındadır. DO değerleri açısından derenin kuzeye yakın kesimlerinde II., III. ve IV. Sınıfta yer almaktadır. Sertlik değeri yüzey suyunda 5.1-21.8 FS arasında değişmekte ve bu değerlere göre su örnekleri "çok yumuşak sular" ile "oldukça sert sular" sınıfları arasında bulunmaktadır. Yüzey sularında gözlenen yüksek sertliğinin nedeni havzada yer alan kumlu kireçtaşı, kireçtaşı ve marnlarda bulunan $\mathrm{Ca}^{+2}$ ve $\mathrm{Mg}^{+2}$ iyonlarının çözünme yolu ile suya geçmesidir.

$\mathrm{Fe}, \mathrm{Mn}, \mathrm{Al}$ ve $\mathrm{Pb}$ değerleri, Söğütlü Deresi'nde akış yönünde güneyden kuzeye doğru artış göstermektedir. Buna göre, su örnekleri iz element değerleri açısından II., III. ve IV. Sınıf'ta yer almaktadır. $\mathrm{NO}_{2}$ değerlerine göre yüzey suları çoğunlukla IV. Sınıf sular sınıfındadır.

Yüzey sularının kalitesini, suda çözünmüş bileşenler belirlemektedir. Ayrıca suyun kalitesi insan faaliyetlerinden de etkilenmektedir. Söğütlü Deresi yüzey suyunda yukarıda adı geçen parametrelerin "Kıta İçi Yüzeysel Su Kaynaklarının Sinıfları"nda tanımlanan sınır değerleri aştığı görülmektedir. Bunun başlıca nedeni çevresel etkilerdir. Bölgede eğimin yüksek olması ve çok yağış alması çözünmüş madde konsantrasyonunu artırmaktadır. Doğu Karadeniz Bölümü'nde son yıllarda, akarsularda denize doğru yaklaştıkça nitrit, nitrat, sülfat, fosfat değerlerinin artış gösterdiği belirlenmiştir (Gültekin vd. 2013). Söğütlü Havzasında yer alan bazik karakterli volkanik kayaçlardan yüzey sularına $\mathrm{Mg}, \mathrm{Na}, \mathrm{K}, \mathrm{Ca}, \mathrm{Cu}, \mathrm{Fe}, \mathrm{Al}, \mathrm{Mn}, \mathrm{Pb}$ çözünerek geçmektedir. Ayrıca Doğu Karadeniz Bölümü'nde yer alan kurşun, çinko ve bakır madenleri de yüzey sularında iyon içeriğinin artmasına neden olmaktadır. Buna ek olarak havzada yerleşim alanlarının sik olması ve atıklarının doğrudan akarsulara deşarj edilmesi de suda organik kirlenmeyi artırmaktadır.

Akarsu havzalarının içme-kullanma suyu olma açısından kalitesini bozan parametrelerin belirlenmesi, bu konuda gerekli önlemlerin alınması ve korunması, akarsuların ileriki yıllarda alternatif kaynak olarak kullanılabilmesi açısından son derece önemlidir. $\mathrm{Bu}$ nedenle havzada yüksek eğime sahip yamaçların kontrol altına alınması, tarımsal faaliyetlerin gerçekleştirildiği bölgelerin atıkları yönünden denetlenmesi gerekmektedir. Ayrıca, bölgede bulunan yerleşim birimlerinin ve sanayi tesislerinin kanalizasyon atıklarını doğrudan Söğütlü Deresi’ne bırakılması engellenmelidir.

\section{KAYNAKLAR}

Celep, S., 2009. Trabzon İli Yeraltı ve Yerüstü Sularının Hidrojeolojik, Hidrokimyasal İncelenmesi ve Su Kalitesinin İncelenmesi. Yüksek Lisans Tezi, KTÜ, Fen Bilimleri Enstitüsü, Trabzon.

Gültekin, F., Fırat Ersoy, A., Hatipoğlu, E. ve Celep, S., 2011. Trabzon İli Akarsularının Yağışlı Dönem $\mathrm{Su}$ Kalitesi Parametrelerinin Belirlenmesi. Ekoloji, 21, 82, 77-88. 
Gültekin, F., Firat Ersoy, A., Hatipoğlu, E. ve Celep, S., 2013. Quality Assessment of Surface and Groundwater in Solaklı Basin (Trabzon, Turkey). Bulletin of Engineering Geology and the Environment, 72, $2,213-224$.

Güven, İ.H., 1993. Doğu Pontidlerin Jeolojisi ve 1/250.000 Ölçekli Kompilasyonu. MTA Yayınları, Ankara, $65 \mathrm{~s}$.

Güven, İ., 1998. 1/100000 Ölçekli Açınsama Nitelikli Türkiye Jeoloji Haritaları, Trabzon-C28 ve D28 paftaları. Jeoloji Etütleri Dairesi, MTA Genel Müdürlüğü, Ankara

Kara, C. ve Çömlekçioğlu, U., 2004. Karaçay (Kahramanmaraş)'ın Kirliliğinin Biyolojik ve Fiziko-Kimyasal Parametrelerle İncelenmesi. KSÜ Fen ve Mühendislik Dergisi, 7, 1.
Ketin, I., 1966. Anadolu'nun Tektonik Birliktelikleri. Maden Tetkik ve Arama Dergisi, 66, 23-34.

Korkmaz, S., 1993. Tonya-Düzköy (GB Trabzon) Yöresinin Stratigrafisi, KTÜ Jeoloji Müh. Bölümü 3. Türkiye Jeoloji Bülteni, 36, 151158.Okay, A.I., Şahintürk, O., 1997. Geology of the eastern Pontides. Report of Regional and Petroleum Geology of the Black Sea and Surrounding Region, 68, 291-311.

Resmi Gazete, 2009. Su Kirliliği Kontrolü Yönetmeliği Numune Alma ve Analiz Metodları, Çevre ve Orman Bakanlığı, Başbakanlık Basımevi. 27372.

TSE 266, 2014. İnsanı Amaçlı Tüketim Suları Standartları, Ankara. 
